\title{
Pengetahuan Ibu Hamil Primigravida Tentang Persiapan Persalinan Di Desa Wonorejo Kecamatan Mojolaban Kabupaten Sukoharjo
}

\author{
${ }^{1}$ Ana Yuliana*, ${ }^{2}$ Tri Wahyuni \\ ${ }^{1}$ Fakultas Ilmu Kesehatan, Universitas Duta Bangsa \\ ${ }^{2}$ Fakultas Ilmu Komputer, Universitas Duta Bangsa
}

\begin{abstract}
Abstrak
Latar Belakang : Ketidaksiapan ibu dalam menghadapi persalinan menjadi salah satu faktor penyebab tingginya AKI yaitu 306 per 100.000 kelahiran hidup pada tahun 2019. Kematian ibu 90\% terjadi pada saat sekitar persalinan dan $95 \%$ penyebab kematian itu adalah komplikasi obstetri yang sering tidak diperkirakan sebelumnya. Pada waktu persalinan jika ditemukan adanya komplikasi obstetri dan ibu tidak mengerti tentang persiapan yang dibutuhkan menjelang persalinan, maka ibu tidak mendapatkan pelayanan yang sesuai dan tepat waktu sehingga terjadi tiga keterlambatan dalam rujukan. Penelitian ini bertujuan untuk mengetahui pengetahuan ibu hamil primigravida tentang persiapan persalinan di Desa Wonorejo Kecamatan Mojolaban Kabupaten Sukoharjo.

Metode Penelitian : Jenis penelitian adalah deskriptif kuantitatif, lokasi penelitian di Desa Wonorejo Kecamatan Mojolaban Kabupaten Sukoharjo, jumlah sampel sebanyak 30 orang, dengan teknik pengambilan sampel menggunakan sampling jenuh. Alat pengumpulan data yang digunakan adalah kuesioner. Analisis data yang digunakan adalah analisa univariat.

Hasil : Pengetahuan ibu hamil primigravida tentang persiapan persalinan mayoritas dalam kategori cukup sebanyak 21 responden $(70 \%)$.

Simpulan : Pengetahuan ibu hamil primigravida tentang persiapan persalinan sebagian besar memiliki pengetahuan cukup yaitu 21 responden (70\%).
\end{abstract}

Kata Kunci : pengetahuan, primigravida, persiapan persalinan

\begin{abstract}
Background: Maternal unpreparedness in facing childbirth is one of the factors causing the high MMR, which is 306 per 100,000 live births in 2019. 90\% of maternal mortality occurred around delivery and 95\% of the causes of death were obstetric complications that were often not predicted beforehand. At the time of delivery, if obstetric complications are found and the mother does not understand the preparations needed for delivery, the mother does not get appropriate and timely services, resulting in three delays in referrals. This study aims to describe the knowledge of primigravida pregnant women about preparation for childbirth in Wonorejo Village, Mojolaban District, Sukoharjo Regency.

Methods: This type of research is quantitative descriptive, the research location is in Wonorejo Village, Mojolaban District, Sukoharjo Regency, the total sample is 30 people, with the sampling technique using saturated sampling. The data collection tool used was a questionnaire. The data analysis used was univariate analysis.

Results: The knowledge of primigravida pregnant women about preparation for delivery was in the moderate category as many as 21 respondents (70\%).

Conclusion: Most of the primigravida pregnant women had sufficient knowledge, namely 21 respondents $(70 \%)$.
\end{abstract}

Keywords: knowledge, primigravida, preparation for delivery 


\section{PENDAHULUAN}

Pembangunan kesehatan pada hakekatnya diarahkan guna tercapainya kesadaran, kemauan dan kemampuan hidup sehat bagi setiap orang, menyangkut fisik, mental, maupun sosial budaya dan ekonomi. Untuk mencapai derajat kesehatan yang optimal dilakukan berbagai upaya pelayanan kesehatan yang menyeluruh, terarah dan berkesinambungan. Masalah kematian ibu dan kematian bayi yang masih tinggi akibat berbagai faktor termasuk pelayanan kesehatan yang relatif kurang baik (Depkes RI, 2014).

Derajat kesehatan suatu negara ditentukan dengan perbandingan tinggi rendahnya tingkat angka kematian ibu dan kematian perinatal Untuk itu diperlukan perhatian yang serius dari berbagai pihak yang terkait dalam memberikan pelayanan kepada ibu dan bayi. Tingginya tingkat angka kematian ibu dan angka kematian perinatal tidak dapat dipisahkan dari profil wanita Indonesia. Pembangunan dibidang kesehatan telah berhasil meningkatkan angka harapan hidup wanita dari tahun per tahun (Depkes RI, 2014).

Angka Kematian Ibu (AKI) merupakan salah satu indikator keberhasilan layanan suatu negara. Setiap hari, sekitar 830 wanita meninggal karena sebab yang dapat dicegah terkait dengan kehamilan dan persalinan. 99\% dari semua kematian ibu terjadi di negara berkembang. Sekitar 830 wanita meninggal karena komplikasi kehamilan atau persalinan di seluruh dunia setiap hari. Salah satu target di bawah Tujuan Pembangunan Berkelanjutan (TPB) 3 adalah untuk mengurangi rasio kematian ibu bersalin global menjadi kurang dari 70 per 100.000 kelahiran, dengan tidak ada negara yang memiliki angka kematian ibu lebih dari dua kali rata-rata global. Wanita meninggal akibat komplikasi selama dan setelah kehamilan dan persalinan. Komplikasi utama yang menyebabkan hampir $75 \%$ dari semua kematian ibu adalah perdarahan hebat setelah melahirkan, infeksi, tekanan darah tinggi selama kehamilan (pre-eklampsia dan eklampsia), komplikasi dari persalinan, dan aborsi yang tidak aman (WHO, 2018).

Bagi ibu primigravida (ibu pertamakali hamil) kehamilan merupakan pengalaman pertama kali dalam periode kehidupannya. Situasi tersebut dapat menyebabkan perubahan drastis baik pada fisik ibu maupun psikologis (Bethsaida dan Pieter, 2013).

Untuk itu, bidan sebagai tenaga kesehatan harus ikut mendukung upaya mempercepat penurunan AKI yaitu diperlukan suatu usaha yang salah satunya adalah pelayanan antenatal atau Antenatal Care (ANC). Pelayanan antenatal merupakan pilar kedua didalam Safe Motherhood yang merupakan sarana agar ibu lebih siap menghadapi persalinan. Ketidaksiapan ibu dalam menghadapi persalinan menjadi salah satu faktor penyebab tingginya AKI. Bila saat persalinan ditemukan adanya komplikasi obstetri dan ibu tidak mengerti tentang persiapan yang dibutuhkan menjelang persalinan, maka ibu tidak mendapatkan pelayanan yang sesuai dan tepat waktu sehingga terjadi tiga keterlambatan dalam rujukan (Depkes RI, 2014).

Persalinan terjadi dimana janin turun ke dalam Usia, paritas ibu hamil, tingkat pendidikan, dan pekerjaan menjadi faktor penyebab munculnya tingkat kecemasan pada ibu hamil primigravida (Handayani, 2015). Usia ibu akan berpengaruh terhadap kehamilan. Usia aman seorang ibu hamil diantara 20 tahun sampai dengan 35 tahun. Sedangkan tingkat pendidikan juga akan berpengaruh pada respon ibu dalam menghadapi sesuatu yang datang dari dalam diri ibu maupun dari luar atau lingkungan (Heriani, 2016).

Kehamilan dan persalinan bagi primigravida merupakan hal yang baru, sehingga ibu kurang mengetahui tanda persalinan maka ibu tidak mengetahui kapan waktu yang tepat untuk pergi ke pelayanan kesehatan.

Hasil Studi Pendahuluan yang dilakukan oleh peneliti pada tanggal 25 Maret 2020 di Desa Wonorejo Kecamatan Mojolaban Kabupaten Sukoharjo terdapat $30 \mathrm{ibu}$ hamil primigravida. Penulis juga melakukan wawancara langsung kepada 5 ibu hamil dimana didapatkan hasil 3 ibu hamil (60\%) yang belum mempersiapkan kebutuhan dalam persalinan diantaranya seperti ibu belum mengetahui tanggal perkiraan persalinan, mental ibu belum siap untuk menghadapi persalinan, tabungan untuk biaya persalinan, ibu belum menyiapkan kendaraan jika sewaktu - waktu diperlukan, dan pakaian untuk bayinya sedangkan 2 ibu hamil $(40 \%)$ sudah mempersiapkan kebutuhan untuk persalinan.

Berdasarkan latar belakang diatas penulis tertarik untuk melakukan penelitian dengan judul Pengetahuan Ibu Hamil Primigravida Tentang Persiapan Persalinan di Desa Wonorejo Kecamatan Mojolaban Kabupaten Sukoharjo.

\section{TINJAUAN PUSTAKA}

\section{Pengetahuan}

Pengetahuan (knowledge) adalah hasil tahu dari manusia, yang sekadar menjawab pertanyaan "what", misalnya apa air, apa manusia, apa alam, dan sebagainya. Pengetahuan hanya dapat menjawab pertanyaan apa sesuatu itu. Apabila pengetahuan itu mempunyai sasaran yang tertentu, mempunyai metode dan pendekatan untuk mengkaji objek tersebut sehingga memperoleh hasil yang disusun secara sistematis dan diakui secara universal. Dengan kata lain, pengetahuan itu dapat berkembang menjadi ilmu (Notoatmodjo, 2012).

Menurut Notoatmodjo (2012) dari berbagai macam cara yang telah digunakan untuk memperoleh kebenaran pengetahuan sepanjang sejarah, dapat dikelompokkan menjadi dua, yakni: cara tradisional atau nonilmiah, yakni tanpa melalui 
penelitian ilmiah, dan cara modern atau cara ilmiah, yakni melalui proses penelitian.

a. Cara Memperoleh Kebenaran Nonilmiah

Cara kuno atau tradisional ini dipakai orang untuk memperoleh kebenaran pengetahuan, sebelumnya ditemukannya metode ilmiah. Caracara penemuan pengetahuan pada periode ini antra lain: (1) Cara Coba Salah, Cara ini dipakai orang sebelum adanya kebudayaan, bahkan ini dilakukan dengan menggunakan kemungkinan dalam memecahkan masalah apabila kemungkinan tersebut dilakukan tidak berhasil akan dicoba dengan kemungkinan yang lain (2) Secara Kebetulan, Penemuan kebenaran secara kebetulan terjadi karena tidak disengaja oleh yang bersangkutan (3) Cara Kekuasaan atau Otoritas, Prinsip dalm cara ini ditemukan orang lain menerima pendapat yang ditemukan oleh orang mempunyai aktifitas tanpa menguji atau membuktikan kebenaran terlebih dahulu berdasarkan fakta empiris atau penalaran sendiri (4) Berdasarkan Pengalaman Pribadi, Pengalaman merupakan sumber pengetahuan, atau pengalaman cara untuk memperoleh kebenaran pengetahuan, apabila gagal tidak akan mengulangi cara itu dan berusaha untuk mencari cara lain dan berusaha untuk mencari cara lain sehingga berhasil (5) Cara Akal Sehat, Cara sehat atau common sense kadangkadang dapat menemukan teori atau kebenaran. Sebelum ilmu pendidikan ini berkembang, para orang tua zaman dahulu agar anaknya mau menuruti nasehat orang tuanya, agar anak disiplin menggunakan cara hukuman fisik bila anaknya berbuat salah (6) Melalui Jalan Fikir, Dalam memperoleh kebenaran pengetahuan manusia telah menggunakan jalan pikkirnya, baik melalui induksi maupun deduksi (7) Induksi, Proses penarikan kesimpulan yang dimulai dari pernyataanpernyataan khusus ke pernyataan yang bersifat umum (8) Deduksi, Pembuatan kesimpulan dari pernyataan-pernyataan umum ke khusus. Proses berpikir berdasarkan pada pengetahuan yang umum mencapai pengetahuan yang khusus.

b. Cara Modern Dalam Memperoleh Pengetahuan

Cara baru dalam memperoleh pengetahuan pada dewasa ini lebih sistematis, logis, dan ilmiah. Caa ini disebut "metode penelitian ilmiah", atau lebih populer disebut metodologi penelitian (research mothodology).

Faktor-faktor Yang Mempengaruhi Pengetahuan Menurut (Wawan dan Dewi, 2010), faktor yang mempengaruhi pengetahuan yaitu pendidikan, pekerjaan, umur, lingkungan dan sosia budaya. Faktor Internal (a) Pendidikan, Pendidikan berarti bimbingan yang diberikan seseorang terhadap perkembangan orang lain menunjukkan manusia untuk berbuatdan mengisi kehidupannya untuk mencapai keselamatan dan kebahagiaan (b) Pekerjaan, Pekerjaan adalah keburukan yang harus dilakukan terutama untuk menunjang kehidupannya dan kehidupan keluarga. Pekerjaan bukan sumber kesenangan tetapi lebih banyak merupakan cara mencari nafkah yang membosankan, berulang dan banyak tantangan (c) Umur, Usia adalah umur individu menghitung mulai sejak lahir sampai berulang tahun. Semakin cukup umur semakin tingkat kematangan dan kekuatan seseorang lebih matang dalam berfikir dan bekerja. Dari segi kepercayaan masyarakat seseorang lebih dewasa dipercaya dari yang sebelum tinggi dewasanya

Faktor Eksternal (a) Faktor Lingkungan, Lingkungan merupakan seluruh kondisi yang ada disekitar manusia dan pengaruhnya yang dapat mempengaruhi perkembangan dan perilaku orang atau kelompok (b) Sosial Budaya, Sistem sosial budaya yang ada pada masyarakat dapat mempengaruhi dari sikap dalam menerima informasi.

Kriteria Tingkat Pengetahuan

Pengetahuan seseorang dapat diketahui dan diinteprestasikan dengan:

a) Baik : hasil presentase $76 \%-100 \%$

b) Cukup : hasil presentase $56 \%-75 \%$

c) Kurang : hasil presentase $<56 \%$

(Wawan dan Dewi, 2010).

\section{Primigravida}

Gravida adalah seorang ibu hamil, Primi yang berarti pertama. Primigravida adalah seorang wanita hamil untuk pertama kali. Kehamilan adalah masa timbulnya dari konsepsi, sampai lahirnya janin, lamanya hamil normal adalah 280 hari (40 minggu atau 9 bulang 7 hari), dihitung dari hari pertama haid terakhir Kehamilan terjadi apabila ada dua pertemuan dan persenyawaan antara sel telur (ovum) dan mani (spermatozoa) lamanya kehamilan di mulai dari ovulasi sampai partus kira-kira 280 hari, lama kehamilan yaitu 280 hari atau 40 minggu, kehamilan di bagi 3 trimester (Prawirohardjo, 2006).

\section{Persiapan Persalinan}

Persalinan merupakan serangkaian kejadian yang berakhir dengan pengeluaran bayi cukup bulan atau hampir cukup bulan, disusul dengan pengeluaran plasenta dan selaput janin dari tubuh ibu (Yanti, 2010). Persiapan persalinan bertujuan untuk menyiapkan semua kebutuhan selama kehamilan maupun proses persalinan. Persiapan persalinan adalah segala sesuatu yang disiapkan dalam hal menyambut kelahiran anak oleh ibu hamil:

a. Persiapan Melahirkan atau bersalin

Macam-macam persiapan melahirkan atau bersalin menurut (Depkes. RI, 2014), adalah

1) Mengetahui tanggal perkiraan persalinan.

2) Suami dan keluarga mendampingi ibu hamil saat bersalin.

3) Siapkan tabungan untuk biaya persalinan.

4) Suami, keluarga, dan masyarakat menyiapkan kendaraan jika sewaktu-waktu diperlukan. 
5) Merencanakan melahirkan ditolong oleh bidan atau dokter di fasilitas pelayanan kesehatan.

6) Menyiapkan orang yang bersedia menjadi donor darah jika sewaktu-waktu diperlukan dengan golongan darah yang sama dengan ibu hamil.

7) Membuat rencana pembuatan keputusan jika terjadi kegawatdaruratan. Hal ini meliputi siapa pembuat keputusan utama dalam keluarga dan siapa yang akan membuat keputusan jika pembuat keputusan utama tidak ada saat terjadi kegawatdaruratan.

Seorang calon ibu dalam mempersiapkan dan menghadapi persalinan dapat mempercayakan dirinya kepada bidan atau dokter. Pertemuan konsultasi dan menyampaikan keluhan, menciptakan hubungan saling mengenal antara calon ibu dan bidan atau dokter yang akan menolongnya (Kusmiyati dkk, 2010).

Standar Antenatal Care (ANC) no 8 tentang persiapan persalinan menyatakan bidan wajib memberikan saran yang tepat kepada ibu hamil, suami dan keluarga ibu hamil pada trimester III, memastikan bahwa persiapan persalinan bersih dan aman dan suasana yang menyenangkan akan direncanakan dengan baik. Mengenai hal ini bidan mengusahakan melakukan kunjungan ke setiap ibu hamil (Depkes RI, 2014).

Calon Ibu dapat memilih tempat persalinan yang diinginkannya karena hal tersebut merupakan hak ibu hamil untuk menentukan dengan cara bagaimana dia akan melahirkan bayinya, namun terkadang proses persalinan tertentu dapat disarankan karena adanya alasan medis (Nurhati, 2009). Selain itu hal-hal yang perlu dipersiapkan dalam kelahiran yaitu : perlengkapan ibu (pakaian, $\mathrm{BH}$, pembalut, celana dalam, kain penutup/jarik, handuk bersih), perlengkapan bayi (popok, pakaian bayi, selendang,topi, selimut, kain gedong, handuk, minyak telon dan bedak bayi) (Depkes. RI, 2014)

Kepala keluarga yang sering melakukan konsultasi telah diberitahukan perkiraan tanggal persalinan, sehingga mereka dapat mempersiapkan diri (Kusmiyati dkk, 2010). Bila tiba-tiba harus melakukan proses persalinan lebih cepat dari jadwal, tidak perlu terburu-buru menyiapkan segala sesuatunya, hal itu justru akan membuat ibu hamil menjadi lebih stres, kemasilah barang - barang yang diperlukan ke dalam tas yang besar dan tempatkan tas tersebut di tempat yang paling mudah diingat (Nurhati, 2009).

b. 4 hal yang harus dipersiapkan dalam persalinan Ada 4 hal yang harus dipersiapkan dalam persalinan menurut (Yuliana, 2018), yaitu persiapan fisik, psikologi, finansial dan kultural.

1) Persiapan Fisik

Proses persalinan adalah proses yang banyak melelahkan,untuk itu perlunya dilakukan persiapan fisik semenjak kehamilan memasuki bulan ke 8 kehamilan, hal ini disebabkan persalinan bisa terjadi kapan saja.
2) Persiapan Psikologi

Proses kelahiran memang menakutkan, apalagi bagi mereka yang baru mengalami kelahiran yang pertama. Pastinya bagi ibu hamil yang akan melahirkan untuk pertama kali, perasaan takut, gugup dan panik akan dialami.

Persiapan pada ibu primigravida pada umumnya belum mempunyai bayangan kejadian - kejadian yang dialami pada akhir kehamilannya saat persalinan terjadi. Salah satu yang harus dipersiapkan ibu menjelang persalinan yaitu hindari kepanikan dan ketakutan dan bersikap tenang, dimana ibu hamil dapat melalui saat - saat persalinan dengan baik dan lebih siap serta meminta dukungan dari orang - orang terdekat, perhatian dan kasih sayang akan membantu memberikan semangat untuk ibu yang akan melahirkan. Keluarga baik orang tua maupun suami merupakan bagian terdekat bagi calon ibu yang dapat memberikan pertimbangan serta bantuan sehingga bagi ibu yang akan melahirkan merupakan motivasi tersendiri sehingga lebih tabah dan lebih siap dalam menghadapi persalinan (Yanti, 2010).

Perasaan cemas pada ibu hamil bisa berdampak pada janin, untuk itu perlu adanya stimulus dari suami untuk menentramkan hati ibu, hal yang dapat dilakukan adalah dengan cara mendengarkan musik. Musik telah di pakai sebagai media pengobatan sejak tahun 550 sebelum Masehi, dan dikembangkan pithagoras dari yunani. Konsep musik ini di terapkan bersama oleh pakar musik Peter Huebner dan komposer - komposer musik klasik jerman, dalam bentuk musik terapi medis resonansi atau istilah asingnya Medical Resonance Therapy Musik, di singkat MRT-M. Daya pengobatan MRT-M ini membawa dampak positif untuk ibu hamil baik yang sehat maupun dengan gangguan. Penurunan angka kelahiran premature merupakan salah satu pengaruh efek pengobatan musik tersebut (Yanti, 2010).

Sebagian besar wanita merasa lebih mampu mengatasi nyeri persalinan bila ditemani oleh seseorang yang mampu memberi dukungan baik mental maupun emosional. Proses persalinan merupakan pengalaman yang menguras banyak tenaga, emosi, serta fisik. Pilihan pertama yang dipilih untuk dapat membagi pengalaman tersebut adalah suami karena suami telah terlibat dengan proses kehamilan sejak awal (MacDougall, 20). Kadangkala ibu hamil tidak mau orang mengetahui bahwa dirinya lemah dan takut sehingga menyembunyikan rasa takut itu dan mengalihkan pikiran ke hal - hal lain. Disarankan agar tidak memendam ketakutan, jika perlu kemukakan hal tersebut pada pasangan atau teman - teman yang pernah mengalaminya. Pengetahuan yang cukup tentang 
proses persalinan dan mengikuti kelas antenal pun dibutuhkan agar ibu hamil siap mental menghadapi persalinan (Nurhati, 2009).

3) Persiapan Finansial

Persiapan finansial bagi ibu yang melahirkan merupakan suatu kebutuhan yang mutlak harus disiapkan, dimana persiapan persalinan atau yang berkaitan dengan menghasilkan atau keuangan yang dimiliki untuk mencukupi kebutuhan selama kehamilan berlangsung sampai persalinan. Kondisi ekonomi berkaitan dengan kemampuan ibu untuk menyiapkan biaya persalinan, persalinan memerlukan biaya yang tidak sedikit. Untuk itu sebaiknya ibu harus mengganggarkan biaya persalinan. Biaya bisa ibu atau keluarga anggarkan dengan tarif persalinan di tempat dimana rencana persalinan akan berlangsung. Selain anggaran biaya persalinan perlu juga menentukan tempat kelahiran sesuai kemampuan. Perencanaan yang adekuat meliputi penentuan tempat yang tepat dengan pertimbangan dalam memilih tempat bersalin yaitu dengan mempertimbangkan jarak tempat bersalin dengan rumah, kualitas pelayanannya, ketersediaan tenaga penolong, fasilitas yang dimiliki, kemampuan pembiayaan dimana setiap klinik atau rumah sakit memiliki ketentuan tarif yang beragam (Yanti, 2010).

Selain anggaran biaya persalinan, perlengkapan ibu dan bayi saat persalinan juga harus disiapkan jauh - jauh hari sebelum tanggal perkiraan persalinan. Hal ini untuk menghindari kekacauan dan kecemasan ibu bila proses persalinan terjadi sebelum tanggal perkiraan persalinan. Perlengkapan bayi yang disiapan meliputi popok, pakaian bayi, kain gedong, handuk, minyak telon, topi. Sedangkan perlengkapan ibu yang harus disiapkan yaitu pakaian, celana dalam, kain penutup/jarik, pembalut, BH, setagen (Depkes RI, 2011).

4) Persiapan Kultural

Ibu harus mengetahui adat istiadat, tradisi dan kebiasaan hidup yang kurang baik terhadap kehamilan dan berusaha mencegah akibat itu. Persiapan yang berhubungan dengan kebiasaan yang tidak baik sebelum kehamilan untuk dihindari selama kehamilan terjadi. Faktor budaya sangat penting dimana terdapat tradisi untuk membawa plasenta ke rumah, cara berperilaku yang benar selama kehamilan dengan menjaga sikap dan perilaku (Yanti, 2010).

Adanya kepercayaan atau pantangan terhadap beberapa makanan pada saat hamil, sementara kegiatan mereka sehari - hari tidak berkurang. Ditambah lagi dengan pantangan pantangan terhadap beberapa makanan yang sebenarnya sangat dibutuhkan oleh ibu hamil, tentunya akan berdampak negative terhadap kesehatan ibu dan janin. Misalnya di daerah
Jawa Tengah, ada kepercayaan bahwa ibu hamil pantang makan telur karena akan mempersulit persalinan dan pantang makan daging karena akan menyebabkan perdarahan yang banyak. Sementara di salah satu daerah jawa barat, ibu yang kehamilannya memasukki 8-9 bulan sengaja harus mengurangi makannya agar bayi yang dikandungnya kecil dan mudah dilahirkan. Menurut tradisi jawa istilah babaran juga dipakai untuk seorang ibu yang melahirkan anaknya. Ubarampe yang dibutuhkan untuk selamatan kelahiran yaitu brokohan (Depkes RI, 2011).

\section{METODE}

Lokasi penelitian di Desa Wonorejo Kecamatan Mojolaban Kabupaten Sukoharjo. Waktu penelitian pada bulan Maret 2020 - Feruari 2021. Desain penelitian yang digunakan dalam penelitian ini adalah deskriptif kuantitatif. Populasi yang digunakan $30 \mathrm{ibu}$ hamil di Desa Wonorejo Kecamatan Mojolaban Kabupaten Sukoharjo. Dalam penelitian ini sampel yang digunakan sejumlah 30 responden dengan teknik pengambilan sampelnya menggunakan Sampel jenuh. Teknik pengumpulan data yang digunakan adalah data primer yaitu pengetahuan ibu hamil primigravida tentang persiapan persalinan yang diukur dengan mengisi kuesioner. Instrumen penelitian yang digunakan dalam penelitian ini yaitu kuesioner.

Adapun tahap-tahap pengolahan data yaitu :

1. Editing yaitu memeriksa semua kuesioner yang masuk mengenai kelengkapannya.

2. Coding yaitu mengklarifikasi data atau jawaban menurut kategorinya dan diberikan kode untuk mempermudah dan pengolahan data yaitu kode B (Benar) dan S (Salah).

3. Scoring yaitu hasil observasi dapat diberikan skor, apabila benar diberi nilai 1 dan apabila salah diberi nilai 0 .

4. Tabulating yaitu membuat tabel-tabel data, sesuai dengan tujuan penelitian.

Analisis data yang digunakan dalam penelitian ini adalah analisis univariat yang bertujuan untuk menjelaskan karakteristik setiap variabel penelitian dimana analisis ini hanya menghasilkan distribusi frekuensi dan prosentase dari setiap variabel.

\section{HASIL DAN PEMBAHASAN}

Penelitian yang dilaksanakan bulan Maret 2020 ini mempunyai tujuan untuk mengetahui pengetahuan ibu hamil primigravida tentang persiapan persalinan di Desa Wonorejo Kecamatan Mojolaban Kabupaten Sukoharjo dengan 30 responden. Sumber - sumber yang didapatkan baik dari data primer maupun sekunder dan setelah dilakukan analisis data maka didapatkan pengetahuan ibu hamil primigravida tentang persiapan persalinan di Desa Wonorejo Kecamatan Mojolaban Kabupaten Sukoharjo. Adapun karakteristik dari responden dalam penelitian ini 
yaitu berdasarkan umur, pendidikan, pekerjaan, informasi.

1. Umur

Tabel 1 Distribusi frekuensi karakteristik umur responden

\begin{tabular}{llll}
\hline No & Umur & Frekuensi & Presentase \\
\hline 1 & $<20$ tahun & 16 & $53,4 \%$ \\
2 & $20-35$ tahun & 14 & $46,6 \%$ \\
3 & $>35$ tahun & 0 & $0 \%$ \\
\hline & Jumlah & 30 & $100 \%$ \\
\hline
\end{tabular}

Tabel 1 Dapat dilihat bahwa dari 30 responden mayoritas berumur $<20$ tahun yaitu 16 orang $(53,, 4 \%)$.

2. Pendidikan

Tabel 2 Distribusi frekuensi karakteristik pendidikan responden

\begin{tabular}{llll}
\hline No & Pendidikan & Frekuensi & Presentase \\
\hline 1 & Dasar (SD) & 8 & $26,7 \%$ \\
2 & $\begin{array}{l}\text { Menengah } \\
\text { (SMP/SMA) }\end{array}$ & 19 & $63,3 \%$ \\
3 & $\begin{array}{l}\text { Perguruan } \\
\text { Tinggi }\end{array}$ & 3 & $10 \%$ \\
\hline & Jumlah & 30 & $100 \%$
\end{tabular}

Tabel 2 Dapat dilihat bahwa dari 30 responden mayoritas pendidikan terakhir adalah SMP/SMA yaitu sebanyak 19 orang $(63,3 \%)$.

3. Pekerjaan

Tabel 3 Distribusi frekuensi karakteristik pekerjaan responden

\begin{tabular}{llll}
\hline No & Pekerjaan & Frekuensi & Presentase \\
\hline 1 & Bekerja & 11 & $36,6 \%$ \\
2 & Tidak & 19 & $63,4 \%$ \\
& Bekerja & & \\
\hline & Jumlah & 30 & $100 \%$ \\
\hline
\end{tabular}

Tabel 3 Dapat dilihat bahwa dari 30 responden mayoritas responden tidak bekerja yaitu sebanyak 19 orang $(63,4 \%)$.

4. Informasi

Tabel 4 Distribusi frekuensi karakteristik responden memperoleh Informasi

\begin{tabular}{llll}
\hline No & $\begin{array}{l}\text { Memperoleh } \\
\text { Informasi }\end{array}$ & Frekuensi & Presentase \\
\hline 1 & $\begin{array}{l}\text { Media Cetak / } \\
\text { Elektronik }\end{array}$ & 5 & $16,7 \%$ \\
2 & $\begin{array}{l}\text { Tenaga Kesehatan } \\
3\end{array}$ & 8 & $26,7 \%$ \\
& $\begin{array}{l}\text { Lingkungan } \\
\text { (Tetangga, } \\
\text { Teman, Saudara) }\end{array}$ & 6 & $20 \%$ \\
& & \\
4 & $\begin{array}{l}\text { Tidak } \\
\text { Memperoleh } \\
\text { Informasi }\end{array}$ & 11 & $36,6 \%$ \\
\hline & Jumlah & 30 & $100 \%$ \\
\hline
\end{tabular}

Tabel 4 Dapat dilihat bahwa dari 30 responden mayoritas responden tidak memperoleh informasi yaitu sebanyak 11 orang $(36,6 \%)$.

Hasil dari penelitian tentang pengetahuan ibu hamil primigravida tentang persiapan persalinan dapat disajikan dalam tabel berikut :

Pengetahuan Ibu Hamil Primigravida Tentang Persiapan Persalinan Di Desa Wonorejo Kecamatan Mojolaban Kabupaten Sukoharjo.

Tabel 5 Distribusi Frekuensi Pengetahuan Ibu Hamil Primigravida Tentang Persiapan Persalinan Di Desa Wonorejo Kecamatan Mojolaban Kabupaten Sukoharjo

\begin{tabular}{llll}
\hline No. & Kriteria & Frekuensi & Prosentase \\
\hline 1 & Baik & 4 & $13,4 \%$ \\
2 & Cukup & 21 & $70 \%$ \\
3 & Kurang & 5 & $16,6 \%$ \\
\hline & Jumlah & 30 & $100 \%$ \\
\hline
\end{tabular}

(Sumber : Data Primer, 2020)

Tabel 5 Dapat diketahui bahwa dari 30 responden mayoritas responden mempunyai pengetahuan yang cukup tentang persiapan persalinan yaitu sebanyak 21 responden $(70 \%)$.

Adapun rincian tabel distribusi frekuensi dari variabel yang diteliti sebagai berikut :

1. Pengetahuan Ibu Hamil Primigravida Tentang Persiapan Fisik Persalinan Di Desa Wonorejo Kecamatan Mojolaban Kabupaten Sukoharjo.

Tabel 6 Distribusi Frekuensi Pengetahuan Ibu Hamil Primigravida Tentang Persiapan Fisik Persalinan Di Desa Wonorejo Kecamatan Mojolaban Kabupaten Sukoharjo

\begin{tabular}{llll}
\hline No. & Kriteria & Frekuensi & Prosentase \\
\hline 1 & Baik & 3 & $10 \%$ \\
2 & Cukup & 6 & $20 \%$ \\
3 & Kurang & 21 & $70 \%$ \\
\hline \multicolumn{2}{c}{ Jumlah } & 30 & $100 \%$ \\
\hline
\end{tabular}

(Sumber : Data Primer, 2020)

Tabel 6 Dapat diketahui bahwa dari 30 responden mayoritas responden mempunyai pengetahuan tentang persiapan fisik persalinan dengan tingkat pengetahuan kurang yaitu 21 responden $(70 \%)$.

2. Pengetahuan Ibu Hamil Primigravida Tentang Persiapan Psikologi Persalinan Di Desa Wonorejo Kecamatan Mojolaban Kabupaten Sukoharjo. 
Tabel 7 Distribusi Frekuensi Pengetahuan Ibu Hamil Primigravida Tentang Persiapan Psikologi Persalinan Di Desa Wonorejo Kecamatan Mojolaban Kabupaten Sukoharjo

\begin{tabular}{llll}
\hline No. & Kriteria & Frekuensi & Prosentase \\
\hline 1 & Baik & 7 & $23,4 \%$ \\
2 & Cukup & 13 & $43,3 \%$ \\
3 & Kurang & 10 & $33,3 \%$ \\
\hline & Jumlah & 30 & $100 \%$ \\
\hline
\end{tabular}

Tabel 7 Dapat diketahui bahwa dari 30 responden mayoritas mempunyai pengetahuan tentang persiapan psikologi persalinan dengan tingkat pengetahuan cukup yaitu 13 responden $(43,3 \%)$.

3. Pengetahuan Ibu Hamil Primigravida Tentang

Persiapan Finansial Persalinan Di Desa

Wonorejo Kecamatan Mojolaban Kabupaten

Sukoharjo.

Tabel 8 Distribusi Frekuensi Pengetahuan Ibu Hamil Primigravida Tentang Persiapan Finansial Persalinan Di Desa Wonorejo Kecamatan Mojolaban Kabupaten Sukoharjo

\begin{tabular}{llll}
\hline No & Kriteria & Frekuensi & Prosentase \\
\hline 1 & Baik & 5 & $16,6 \%$ \\
2 & Cukup & 18 & $60 \%$ \\
3 & Kurang & 7 & $23,4 \%$ \\
\hline & Jumlah & 30 & $100 \%$ \\
\hline
\end{tabular}

(Sumber : Data Primer, 2020)

Tabel 8 Dapat diketahui bahwa dari 30 responden mayoritas mempunyai pengetahuan tentang persiapan finansial persalinan dengan tingkat pengetahuan cukup yaitu 18 responden $(60 \%)$.

4. Pengetahuan Ibu Hamil Primigravida Tentang Persiapan Kultural Persalinan Di Desa Wonorejo Kecamatan Mojolaban Kabupaten Sukoharjo.

Tabel 9 Distribusi Frekuensi Pengetahuan Ibu Hamil Primigravida Tentang Persiapan Kultural Persalinan Di Desa Wonorejo Kecamatan Mojolaban Kabupaten Sukoharjo

\begin{tabular}{llll}
\hline No. & Kriteria & Frekuensi & Prosentase \\
\hline 1 & Baik & 3 & $10 \%$ \\
2 & Cukup & 5 & $16,6 \%$ \\
3 & Kurang & 22 & $73,4 \%$ \\
\hline & Jumlah & 30 & $100 \%$ \\
\hline
\end{tabular}

(Sumber : Data Primer, 2020)

Tabel 9 Dapat diketahui bahwa dari 30 responden mayoritas mempunyai pengetahuan tentang persiapan kultural persalinan dengan tingkat pengetahuan kurang yaitu 22 responden $(73,4 \%)$

\section{PEMBAHASAAN}

Hasil penelitian yang telah disajikan dalam bentuk tabel distribusi yaitu pada tabel 5 yang berjudul Pengetahuan Ibu Hamil Primigravida Tentang Persiapan Persalinan Di Desa Wonorejo Kecamatan Mojolaban Kabupaten Sukoharjo. menunjukkan bahwa dari 30 responden di Desa Wonorejo Kecamatan Mojolaban Kabupaten Sukoharjo, sebanyak 4 responden $(13,4 \%)$ dalam kategori baik, 21 responden $(70 \%)$ dalam kategori cukup dan 5 responden (16,6\%) dalam kategori kurang. Dari data tersebut dapat disimpulkan bahwa responden mempunyai pengetahuan yang cukup tentang persiapan persalinan hal ini dipengaruhi oleh faktor umur, pendidikan, pekerjaan, informasi.

Pengetahuan (knowledge) adalah hasil tahu dari manusia terhadap objek melalui indra yang dimiliki (mata, hidung, telinga, dan sebagainya). Pada penginderaan sampai hasil pengetahuan tersebut sangat dipengaruhi oleh intensitas perhatian dan persepsi terhadap objek (Notoatmodjo, 2012) dimana hasil dari pengetahuan ibu hamil primigravida di Desa Wonorejo Kecamatan Mojolaban Kabupaten Sukoharjo mayoritas dapat dikategorikan berpengetahuan cukup.

Sesuai hasil yang diperoleh dalam penelitian yaitu sebagian besar responden mempunyai tingkat pengetahuan cukup karena dipengaruhi oleh umur. Semakin tua umur seseorang maka proses - proses perkembangan mentalnya semakin baik, akan tetapi pada umur tertentu, bertambahnya proses perkembangan mental ini tidak secepat seperti kita berumur belasan tahun jadi dapat disimpulkan bertambahnya umur seseorang dapat berpengaruh pada pertambahan pengetahuan yang di perolehnya (Sari, 2008).

Pengetahuan dipengaruhi oleh pendidikan dan pendidikan dipengaruhi oleh banyak hal diantaranya adalah sumber informasi dan media informasi, baik media cetak, elektronik, human media antara lain bidan (Soekanto, 2007).

Selain pendidikan pengetahuan seseorang juga dipengaruhi oleh pekerjaan. Pekerjaan merupakan aktivitas atau kegiatan yang dilakukan oleh responden sehingga memperoleh penghasilan (Notoatmodjo, 2012). Mayoritas responden memiliki pengetahuan cukup yaitu 21 responden (70\%). Dalam hal ini pengetahuan responden dipengaruhi umur, pendidikan, pekerjaan. Selanjutnya penelitian akan membahas satu per satu variabel yang diteliti sebagai berikut :

1. Pengetahuan Ibu Hamil Primigravida tentang Persiapan Fisik Persalinan Desa Wonorejo Kecamatan Mojolaban Kabupaten Sukoharjo. 
Tabel 5 menunjukkan bahwa pengetahuan ibu hamil primigravida tentang persiapan fisik persalinan dari 30 responden, sebanyak 3 responden (10\%) mempunyai pengetahuan baik, 6 responden $(20 \%)$ mempunyai pengetahuan cukup dan 21 responden $(70 \%)$ mempunyai pengetahuan kurang. Dari data tersebut dapat disimpulkan bahwa sebagian besar responden mempunyai pengetahuan kurang tentang persiapan fisik persalinan.

Sebagian besar responden memiliki umur $<20$ tahun $(53,4 \%)$.

Dilihat dari umur responden, masih banyak yang berumur muda sehingga belum cukup matang. Hal ini dapat mempengaruhi pengetahuan yang diperolehnya.

Umur dapat mempengaruhi seseorang, pada umumnya semakin cukup umur maka tingkat kematangan dan kekuatan seseorang akan lebih matang dalam berfikir sehingga pengalaman akan lebih banyak (Wawan dan Dewi, 2010).

Hal ini sama dengan Penelitian yang telah dilakukan oleh Anggraini ( 2011) yang berjudul Faktor - Faktor Yang Berhubungan Dengan Pengetahuan Tentang Nutrisi Pada Ibu Hamil Di BPM Ningwaryatun Karanganyar. Dalam penelitian tersebut menunjukkan adanya hubungan antara umur dengan pengetahuan ibu hamil mengenai nutrisi pada saat kehamilan. Umur yang masih muda belum begitu mengetahui tentang nutrisi yang dibutuhkan ibu hamil. Umur seseorang sangat mempengaruhi daya tangkap dan pola pikir, semakin matang umur maka akan semakin berkembang pula daya tangkap dan pola pikirnya sehingga pengetahuan yang diperoleh semakin membaik.

2. Pengetahuan Ibu Hamil Primigravida tentang Persiapan Psikologi Persalinan Di Desa Wonorejo Kecamatan Mojolaban Kabupaten Sukoharjo.

Tabel 6 menunjukkan bahwa tingkat pengetahuan ibu hamil primigravida tentang persiapan psikologi persalinan dari 30 responden sebanyak 7 responden $(23,4 \%)$ memiliki pengetahuan baik, 13 responden $(43,3 \%)$ memiliki pengetahuan cukup, dan 10 responden $(33,3 \%)$ memiliki pengetahuan kurang. Dari data tersebut maka dapat disimpulkan bahwa sebagian besar responden mempunyai pengetahuan yang cukup tentang persiapan psikologi persalinan.

Mayoritas responden tidak bekerja $(63,4 \%)$ sehingga responden lebih banyak memiliki waktu luang untuk menambah pengetahuan dengan cara mencari informasi dari media massa atau melakukan konseling langsung dengan tenaga kesehatan. Sebagian besar responden berpengetahuan cukup dipengaruhi oleh pekerjaan. Sebagai ibu rumah tangga atau wanita yang tidak bekerja wanita usia subur dapat memperoleh informasi yang banyak baik dari teman, media massa atau terutama dari tenaga kesehatan karena memiliki waktu luang yang lebih banyak untuk bersosialisasi dibandingkan dengan wanita yang bekerja.

Pekerjaan bukanlah sumber kesenangan, tetapi lebih banyak merupakan cara mencari nafkah yang membosankan, berulang dan banyak tantangan. Sedangkan bekerja pada umumnya merupakan kegiatan yang menyita waktu. Bekerja bagi ibu - ibu akan mempunyai pengaruh terhadap kehidupan keluarga ( Wawan dan Dewi, 2011 ).

Hal ini sejalan dengan penelitian yang dilakukan oleh Sumiyati (2008) dengan judul Hubungan Pengetahuan Persalinan Dengan Kesiapan Dalam Menghadapi Persalinan Pada Primigravida Di RB Suko Asih Sukaharjo. Hasil penelitian menunjukkan bahwa ada hubungan antara pekerjaan dengan pengetahuan ibu hamil tentang persiapan persalinan. Ibu yang tidak bekerja lebih banyak memiliki waktu luang untuk mancari informasi dan melakukan konseling langsung dengan tenaga kesehatan, beda dengan ibu yang bekerja tidak ada waktu untuk melakukan konseling langsung dengan tenaga kesehatan karena sibuk dengan pekerjaannya.

3. Pengetahuan Ibu Hamil Primigravida tentang Persiapan Finansial Persalinan Di Desa Wonorejo Kecamatan Mojolaban Kabupaten Sukoharjo.

Tabel 7 menunjukkan bahwa gambaran pengetahuan ibu hamil primigravida tentang persiapan finansial persalinan dari 30 responden sebanyak 5 responden $(16,6 \%)$ memiliki pengetahuan baik, 18 responden $(60 \%)$ memiliki pengetahuan cukup dan 7 responden $(23,4 \%)$ memilki pengetahuan kurang. Dari data tersebut maka dapat disimpulkan bahwa sebagian besar responden mempunyai pengetahuan yang cukup tentang persiapan finansial persalinan.

Pengetahuan responden cukup dipengaruhi faktor pendidikan, dimana mayoritas responden berpendidikan SMP/SMA (63,3\%). Pendidikan formal dapat mempengaruhi pengetahuan sehingga dapat menghasilkan perubahan pengetahuan menjadi lebih baik.

Pendidikan dapat mempengaruhi seseorang termasuk juga perilaku seseorang akan pola hidup terutama dalam memotivasi untuk sikap berperan serta dalam pembangunan dan untuk memperoleh informasi sehingga dapat menunjang kualitas hidup ( Wawan dan Dewi, 2010 ).

Hal ini sama dengan penelitian yang dilakukan oleh Fitriani (2011) dengan judul Hubungan Pengetahuan Ibu Hamil Primigravida Dengan Persiapan Menghadapi Persalinan Di Puskesmas Penumping Surakarta. Hasil penelitian menunjukkan bahwa ada hubungan antara pendidikan dengan pengetahuan ibu hamil primigravida tentang persiapan menghadapi persalinan. Dengan pendidikan tinggi maka 
seseorang akan cenderung untuk mendapatkan informasi baik dari orang lain maupun dari media massa sehingga mempengaruhi pengetahuannya.

4,. Pengetahuan Ibu . Hamil Primigravida tentang Persiapan Kultural Persalinan Di Desa Wonorejo Kecamatan Mojolaban Kabupaten Sukoharjo.

Tabel 8 menunjukkan bahwa tingkat pengetahuan ibu hamil primigravida tentang persiapan kultural persalinan dari 30 responden sebanyak 3 responden $(10 \%)$ memiliki pengetahuan baik, 5 responden $(16,6 \%)$ memiliki pengetahuan cukup, dan 22 responden $(73,4 \%)$ memiliki pengetahuan kurang. Dari data tersebut maka dapat disimpulkan bahwa sebagian besar responden mempunyai pengetahuan yang kurang tentang persiapan kultural persalinan.

Pengetahuan responden yang kurang dipengaruhi faktor informasi. Dimana mayoritas responden tidak memperoleh informasi $(36,6 \%)$. Misalnya informasi langsung dari tenaga kesehatan melalui penyuluhan kesehatan, yaitu penyuluhan kesehatan tentang persiapan persalinan.

Informasi yang diperoleh baik dari pendidikan formal maupun non formal dapat memberikan pengaruh jangka pendek sehingga menghasilkan perubahan atau peningkatan pengetahuan ( Notoatmodjo, 2007).

Hal ini sama dengan penelitian yang dilakukan oleh Hilda (2010) dengan judul Pengaruh Kebudayaan Terhadap Pengetahuan Dan Sikap Ibu Hamil Trimester III Menghadapi Persalinan Di BPM Sri Mulyani Sukoharjo. Penelitian ini menunjukkan adanya pengaruh positif penyuluhan kesehatan terhadap pengetahuan tentang persiapan persalinan sehingga penyuluhan kesehatan dapat meningkatkan pengetahuan ibu hamil tentang persiapan persalinan. Dan ada pengaruh positif penyuluhan kesehatan terhadap sikap menghadapi persalinan.

\section{KESIMPULAN}

Berdasarkan hasil penelitian terhadap 30 responden tentang Pengetahuan Ibu Hamil Primigravida Tentang Persiapan Persalinan Di Desa Wonorejo Kecamatan Mojolaban Kabupaten Sukoharjo, dapat disimpulkan bahwa tingkat pengetahuan tentang persiapan persalinan pada ibu hamil primigravida yaitu :

1. pengetahuan ibu hamil primigravida tentang persiapan persalinan di Desa Wonorejo Kecamatan Mojolaban Kabupaten Sukoharjo tahun 2020 bahwa sebagian besar responden mempunyai tingkat pengetahuan cukup.

2. pengetahuan ibu hamil primigravida tentang persiapan fisik persalinan di Desa Wonorejo Kecamatan Mojolaban Kabupaten Sukoharjo tahun 2020 bahwa sebagian besar responden mempunyai tingkat pengetahuan kurang.

3. pengetahuan ibu hamil primigravida tentang persiapan psikologi persalinan di Desa
Wonorejo Kecamatan Mojolaban Kabupaten Sukoharjo tahun 2020 bahwa sebagian besar responden mempunyai tingkat pengetahuan cukup.

4. pengetahuan ibu hamil primigravida tentang persiapan finansial persalinan di Desa Wonorejo Kecamatan Mojolaban Kabupaten Sukoharjo tahun 2020 bahwa sebagian besar responden mempunyai tingkat pengetahuan cukup.

5. pengetahuan ibu hamil primigravida tentang Persiapan kultural persalinan di Desa Wonorejo Kecamatan Mojolaban Kabupaten Sukoharjo tahun 2020 bahwa sebagian besar responden mempunyai tingkat pengetahuan kurang.

\section{Saran}

1. Bagi Instansi Tempat Penelitian

Diharapkan bagi bidan atau petugas kesehatan dapat memberikan informasi atau penyuluhan kepada ibu primigravida tentang persiapan persalinan.

2. Bagi Responden

Diharapkan responden lebih meningkatkan pengetahuan tentang persiapan persalinan dengan cara banyak membaca buku, mencari sumber dari media cetak atau elektronik seperti internet, koran, dan majalah.

3. Bagi Institusi pendidikan

Diharapkan hasil penelitian dapat menambah bahan bacaan atau referensi tentang pengetahuan ibu primigravida tentang persiapan persalinan.

4. Bagi Peneliti

Diharapkan bagi peneliti selanjutnya hasil penelitian dapat bermanfaat dan dapat digunakan sebagai bahan pembanding bagi peneliti - penelitian selanjutnya dan dapat juga mengembangkan variabel penelitian yang berbeda misal dengan dua variabel, metode penelitian yang berbeda misal dengan metode penelitian analitik kualitatif, jumlah populasi dan sampel yang lebih banyak dari sampel yang digunakan dalam penelitian ini, sehingga akan diperoleh hasil yang lebih baik lagi.

\section{DAFTAR PUSTAKA}

Anggraini. 2011. Faktor-faktor yang berhubungan dengan pengetahuan tentang nutrisi pada ibu hamil di BPM Ningwaryatun [KTI] Karanganyar: Program Studi Diploma III Kebidanan Mitra Husada.

Arikunto S. 2010. Prosedur penelitian suatu pendekatan praktek. Jakarta: Rineka Cipta.

Depkes RI. 2014. Standar pelayanan kebidanan. Jakarta: Depkes RI. Didapat dari: http://www.depkes.go.id

Depkes RI. 2011. Budaya daerah tentang ibu hamil. Jakarta: Depkes RI. Didapat dari: http://www.depkes.go.id 
Fitriani. 2011. Hubungan pengetahuan ibu hamil primigravida dengan persiapan menghadapi persalinan di Puskesmas Penumping [KTI] Surakarta : Program Studi Diploma III Kebidanan Mitra Husada.

Hastono, Sabri P. 2011. Statistik kesehatan. Jakarta: Rajawali Pers.

Hidayat A. 2010. Metodologi penelitian keperawatan dan teknik analitik data. Jakarta: Salemba Medika.

Hilda. 2010. Pengaruh kebudayaan terhadap pengetahuan dan sikap ibu hamil trimester III menghadapi persalinan di BPM Sri Mulyani [KTI] Sukoharjo: Program Studi Diploma III Kebidanan Mitra Husada.

Kusmiyati. 2010. Y.H.P, Wahyuningsih dan Sujiyatini. Perawatan ibu hamil. Yogyakarta: Fitramaya.

Macdougall, J. 2014. Kehamilan minggu demi minggu. Jakarta: Erlangga.

Notoatmodjo S. 2012. Metodologi penelitian kesehatan. Jakarta: Rineka Cipta; 2012.
Rahmaningrum. 2019. Tingkat pengetahuan ibu hamil trimester III tentang persiapan persalinan di BPS Ariyanti Gemolong [KTI]. Surakarta: Program Studi Diploma III Kebidanan Sekolah Tinggi Ilmu Kesehatan Kusuma Husada.

Saifuddin A. Rachimhadi BT, Wiknjosastro GH. 2010. Ilmu kebidanan sarwono prawirohardjo.Jakarta: PT. Bina Pustaka Sarwono Prawirohardjo.

Setyowati. 2019. Gambaran pengetahuan ibu hamil tentang persiapan persalinan di BPS Supriharini [KTI]. Karanganyar: Program Studi Diploma III Kebidanan Mitra Husada.

Setiawan A, Saryono. 2012. Metodologi penelitian kebidanan DIII, DIV, S1 dan S2.Yogyakarta: Nuha Medika.

Wawan dan Dewi M. 2010. Pengetahuan dan sikap perilaku manusia. Yogyakarta: Nuha Medik.

Yanti. 2010. Buku ajar asuhan kebidanan persalinan. Yogyakarta: Pustaka Rihama 